\title{
Proposed ELR Model for E-Learning Readiness Evaluation Based on McKensey 7S Framework
}

\author{
Darmawan Napitupulu 1, 2, Krisna Adiyarta ${ }^{2}$, Dahlan Abdullah ${ }^{3}$, Dewi Murtiningsih ${ }^{4}$ \\ \{darwan.na70@gmail.com ${ }^{1}$,krisna.adiyarta@gmail.com ${ }^{2}$,dahlan@unimal.ac.id ${ }^{3}$, \\ dewi.murtiningsih@budiluhur.ac.id $\left.{ }^{4}\right\}$
}

\author{
${ }^{1}$ Research Center for Quality System \& Testing Technology, Indonesian Institute of Sciences, Tangsel, \\ Indonesia \\ ${ }^{2}$ Program Studi Magister Ilmu Komputer, UniversitasBudi Luhur, Jl. Ciledug Raya, Jakarta, Indonesia \\ ${ }^{3}$ Department of Informatics, Universitas Malikussaleh, Aceh, Indonesia \\ ${ }^{4}$ Fakultas Ekonomi dan Bisnis, Universitas Budi Luhur, Jl. Ciledug Raya, Jakarta, Indonesia
}

\begin{abstract}
One of the utilization of ICT in education including higher education is known as electronic learning (e-learning). E-learning can be interpreted as the delivery of learning content or learning experiences electronically based multimedia computer. Utilization of e-learning well can improve learning outcomes optimally. Lots of advantages e-learning utilization but the failure in the implementation of e-learning is still common despite being supported with large funds and preparation. One of the causes of elearning failure is the lack of readiness level information in e-learning implementation. ELR model can be used to measure the level of organizational readiness and know which factors of readiness are still weak so that require improvement or improvement. This study aims to propose ELR models from several best practice ELR models over the last 10 years. The research method used is by synthesis and mapping the readiness factors into the McKensey $7 \mathrm{~s}$ framework so as to produce an intact model consisting of dimensions and factors. The result of the research shows that there are 17 ELR factors which are psychological, sociological, environmental, human resource, financial, knowledge \& skill, infrastructure, content, management, leadership, culture, policy, teacher experience, training, organization structure, technical support and laws \& regulation. The overall factors are mapped with the McKensey 7S framework into 7 dimensions: strategy, structure, systems, style/culture, staff, skills and shared values.
\end{abstract}

Keywords: E-Learning, Readiness, ELR, Model, Evaluation, McKensey.

\section{Introduction}

One of the utilization of ICT in education including higher education is known as electronic learning (e-learning). Definitively, e-learning can be interpreted as the delivery of learning content or learning experience electronically based on multimedia computer (Waryanto, 2014). Utilization of e-learning well can improve learning outcomes optimally. Lots of advantages of e-learning utilization include: (1) Shorten the learning time and make the study cost more economical (2) Facilitate the interaction between learners with materials, (3) Mutual information and can access learning materials at any time and repeatedly so that learners can further improve the mastery of the material, (4) The process of knowledge development does not only occur in the classroom, but with the help of computer and network equipment, learners can be actively involved in the teaching and learning process. Teaching standardization, e-learning lessons always have the same quality whenever accessed and independent of the mood of the teacher and (6) the effectiveness of teaching, the delivery of e- 
learning lessons can be case-based, using game form along with technology modern animation (Rohmah, 2016), (Sensuse, D I., Napitupulu, 2017) Although the potential of e-learning is very large, it turns out that the implementation of e-learning requires a lot of cost and proper planning, failure in the implementation of e-learning is still common despite being supported with large funds and preparation (Sun, P.C., 2008). Some things that can lead to the failure of the implementation of e-learning system that is (Waryanto, 2014), (Rachman T., Napitupulu D., 2017):

- The quality of human resources (HR) is lacking, lack of human resources training and no technicians

- Lack of reference to e-learning implementation and not knowing readiness level information

- Inadequate infrastructure and limited internet network

- Organizational culture and leadership factors are less supportive

Implementation of e-learning requires the readiness of both infrastructure and agency culture. This readiness is known as E-learning Readiness (ELR). According to Borotis \& Poulymenakou (Priyanto, 2008), ELR is an organization's mental and physical readiness for an e-learning experience or action (Borotis, S., Poulymenakou, A., 2004). ELR also influences the success of educational programs that use information and communication technology in the academic process (Kaur, K., Abas, 2004). Measurement of the degree of readiness is based on the components of the ELR. The ELR model is designed to simplify the process of obtaining the basic information necessary to measure e-learning readiness. The ELR model in the analysis phase is used to compile the requirement document that becomes the base line for the design, development and implementation phase. While at the evaluation stage, the ELR model is used to measure success and determine recycling decision for improvement process in the next period. ELR model is not only to measure the degree of readiness of institutions to implement e-learning, but more important is to reveal which factors or areas are still weak so it needs improvement and which areas are considered successful or strong in supporting elearning implementation. By knowing the level of readiness and which areas should be developed, it is expected that the agency can determine the policy or strategy that will be done in order to implement e-learning success and useful. In this research, ELR model was proposed by integrating some existing best practice ELR models. It is expected that this ELR model can be used as an analytical tool or evaluation of readiness toward e-learning system implementation so that it could improve the success rate in the future (Ralmugiz, 2015); (Saekow, A., Samson, 2011); (Rachman T., Napitupulu D., 2017).

As mentioned before, evaluation or measurement of e-learning readiness is needed to know which factors are already strong or weak and require continuous improvement. Some studies that have been done before can be described as follows:

- (Waryanto, 2014) examines the readiness of e-learning in high schools in Yogyakarta City, the readiness level score of the eight categories of e-learning Readiness (ELR) Chapnick Model, obtained the total score of E- learning Readiness for State Senior High Schools in Kota Yogyakarta that is equal to 103,76 . Thus it can be said that SMA Negeri in Yogyakarta City is quite ready for the implementation of e-learning in the learning process. The category that has a high degree of readiness is the category of Sociological readiness. This relates to factors that consider the interpersonal aspects of the environment in which the process will be implemented. Category that has enough level of readiness is Psychological readiness, Financial Readiness, Equipment readiness, and Content readiness.

- (Achieng, H., 2013) examines the ELR Assessment Model in Higher Education 
Institutions: A Case Study of the University of Nairobi. This study aims to determine the best ELR model for evaluating e-learning at the University of Nairobi, and after that also determines the degree of readiness of e-learning at the University of Nairobi using the Aydin \& Tasci e-learning readiness index. After the research, the four components proposed to be ELR model components are: demographic factors, technological readiness, content readiness and culture readiness, only two components affect the ELR: technological readiness and culture readiness.

- (Landipayana, 2013) examines the Evaluation of E-learning Using Value Model (Case Study E-learning Department of Information Systems Institute of Technology Sepuluh Nopember). This research uses 3-Layer Value Model for e-learning that is: efficiency layer, effectiveness layer, and impact layer of future behavior of each user. From the results of data collection and then the data is analyzed, it is known the priority of improvement that must be done is on the learning community that is communication, team learning and exchange ideas.

Meanwhile, some researchers have developed an ELR (e-learning readiness) model that is widely used to measure the level of readiness of e-learning implementation as the basis of elearning development strategy because e-learning readiness model is a very effective instrument to evaluate organizational strategy in development e-learning. The ELR model is considered appropriate for escorting e-learning travel from analysis to evaluation (Rosenberg, M.J., 2006). This is important even (Chapnick, S., 2000) and (Aydin C H., Tasci, 2005) warned organizations should be cautious in the e-learning adoption process. They affirm that e-learning adoption without careful planning and strategy is likely to end in cost overruns, unattractive learning products, and failures. The ELR model proposed by (Chapnick, S., 2000) has been widely used, even adopted by the Ministry of Education (MOE) Singapore in the planning of e-learning development at schools in Singapore (Swatman, T., So, 2005). (Chapnick, S., 2000) grouped the readiness of e-learning implementation into eight preparedness categories:

- Psychological readiness: This factor considers the individual's perspective on the influence of e-learning initiatives. This is the most important factor for the sabotage of the implementation process.

- Sociological readiness: This factor considers the interpersonal aspects of the environment in which the program will be implemented.

- Environmental readiness: This factor considers the operation of large forces to stakeholders, both within and outside the organization.

- Human resource readiness: This factor considers the availability and design of a human resources support system.

- Financial readiness: This factor considers the size of the budget and the allocation process.

- Technological skill readiness: This factor considers the technical competencies that can be observed and measured.

- Equipment readiness: This factor considers the ownership of the appropriate equipment.

- Content readiness: This factor considers the learning content and learning objectives.

The other researchers who developed the ELR model that can be identified successively as Kirkpatrick proposed ELR model consists of 4 (four) levels of reaction, knowledge, behavior and result. These four levels further illustrate the evaluation of the results obtained by an institution after implementing e-learning. There are a number of assessments that can be used as information for each characteristic (Prayudi, 2009), (Swatman, T., So, 2005) developed ELR model based on six assessment components: Student's Preparedness, Teacher's Preparedness, IT infrastructure, Management Support, School Culture and Preface to meet 
face-to- face. (Akaslah, D., Effie, L., 2011) also proposed ELR model based on three components: Technology, People, Content and Institution. (Saekow, A., Samson, 2011), developed ELR model for higher education in Thailand which consisted of five dimensions of measurement namely Policy, Technology, Financial, Human Resources and Infrastructure. (Kaur, K., Abas, 2004) proposed ELR model for Malaysia which had several components of assessment that are Learner, Management, Personnel, Content, Technical, Environment, Culture and Financial

\section{Research Methodology}

Based on literature studies conducted on the ELR model, in this section a total of 8 studies were selected from various literatures related to the theme of research over the past 10 years. The entire study was drawn from Scopus' international database of reputable publishers IEEE, Wiley, Elsevier, Inderscience, etc. Several studies synthesized to produce generic ELR models are widely used ELR models. All ELR Hussein (2010) has 7 factors, ELR Hussein model (2011) consists of 8 factors, ELR (Saekow, A., Samson, 2011) model has 7 factors, the ELR (Darab, B., Montazer, 2011) model also has 7 factors of readiness, ELR (Wattakiecharoen, J., Nilsook, 2013) model has 5 factors and ELR model (Akaslah, D., Effie, L., 2011)has proposed 4 factors of readiness. Some of the ELR models mentioned above will be integrated with the (Chapnick, S., 2000) model as the model base in this study.

The ELR model containing the readiness factors from the synthesis results will be mapped into the McKinsey 7S framework with the aim of categorizing ELR factors into the assessment dimension so that it can be used to measure the ELR. The McKinsey 7S Framework was developed in the early 1980 s by Tom Peters and Robert Waterman, two consultants working for the McKinsey \& Company consulting firm and has been used to analyze more than 70 organizations worldwide (Alshaher. A A., 2013), (Ralmugiz, 2015). The premise of a model that has seven internal organizational aspects is related to each other for the sake of success in organizational sustainability. The basic idea of this model is the seven aspects or internal elements of the organization. The McKinsey 7S Framework can be presented in Figure 1 as follows:

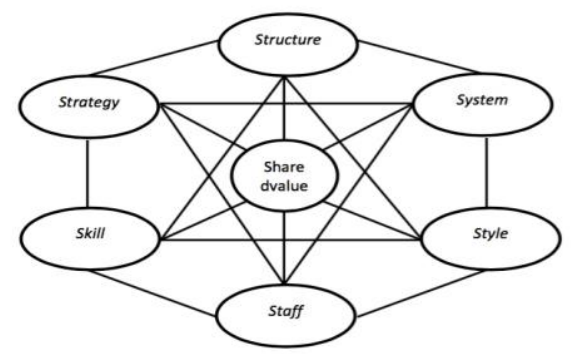

Figure 1: Framework of McKensey 7S (Alshaher, 2013).

Based on Figure 1 above we can see the comprehensive McKensey 7S framework consists of seven elements: strategy, structure, style, system, staff, skill, and shared value (Hanafizadeh et.al 2011). The 7 (seven) elements are categorized as "hard" and "soft" elements. The "hard" element is easy to define as strategy, structure and system, while the "soft" element is more difficult element to measure is staff, skill, style and shared value (Alshaher. A A., 2013) 


\section{Result \& Discussions}

This section describes the results of research consisting of 2 stages: identification and synthesis of ELR factors in the implementation of e-learning involving 8 (eight) studies. Then the synthesis results of ELR factors will be mapped into the McKinsey 7S framework where the framework is often used by management in measurement of information systems such as Enterprise Resource Planning (ERP) but McKinsey 7S model has elements covering all components related to evaluating e- Learning (Alshaher. A A., 2013), (Ralmugiz, 2015). The ELR model synthesis results that illustrate the factors of readiness in the application of eLearning can be presented in Table 1 below. Each factor found in the ELR model is considered as the readiness factor of e-Learning implementation in this research.

Based on Table 1, the synthesis process of 8 best practice ELR models has resulted in 17 factors that must be adopted by the organization in implementing e-Learning system that is psychological, sociological, environmental, human resource, financial, knowledge \& skill, ICT infrastructure, innovation, management, leadership culture, policy, experience of teacher, training, organization structure, technical support and laws \& regulation. The entire synthesized factor has the same degree of degree, nothing more important than others. However in this research, ELR factors are analyzed based on frequency which is aimed to prepare the priority level of readiness factors of e-learning implementation as can be seen in Table 2.

Based on Table 2, it can be seen that there are 17 readiness factors obtained from the best practice ELR model. Human Resource Factor is the factor most widely adopted by existing ELR model with frequency 8. In other words, Human Resource availability factor is a factor that is considered critical in the successful implementation of e-learning system in organization.

The next factor based on the highest frequency level is the factor of ICT Infrastructure and Knowledge \& Skill factors. The condition of ICT Infrastructure that support becomes one of the important factors of readiness in the implementation of e-learning. Besides Knowledge \& Skill is an important factor that must be owned especially by users both teachers and students in supporting the successful implementation of e-learning system.

The next step is to mapping the synthesized ELR factors into the McKensey $7 \mathrm{~S}$ framework that has seven dimensions or readiness factors. This framework is also developed for institutions in developing countries, so it is appropriate if applied in Indonesia as a developing country.

Framework of McKensey $7 \mathrm{~S}$ can be applied before or after the implementation of elearning in learning. This framework will be able to provide a score of readiness level of elearning implementation in the organization so that it can be known which readiness factors are still weak and require improvement or improvement in the application of e-learning system. The mapping results of 17 ELR factors that have been synthesized from 8 ELR models can be presented in Table 3 .

Table 1. Synthesizing model ELR (E-Learning Readiness).

\begin{tabular}{llllllllll}
\hline No & $\begin{array}{c}\text { E-learning } \\
\text { Readiness } \\
\text { Factor }\end{array}$ & $\begin{array}{c}\text { Chapnick } \\
(2000)\end{array}$ & $\begin{array}{c}\text { Schreurs } \\
(2008)\end{array}$ & $\begin{array}{c}\text { Hussein } \\
(2010)\end{array}$ & $\begin{array}{c}\text { Fageeh } \\
(2011)\end{array}$ & $\begin{array}{c}\text { Saekow } \\
\text { \& } \\
\text { Samson } \\
(2011)\end{array}$ & $\begin{array}{c}\text { Darab \& } \\
\text { Montazer } \\
(2011)\end{array}$ & $\begin{array}{c}\text { Wattakiecharo } \\
\text { en \& Nilsook } \\
(2011)\end{array}$ & $\begin{array}{c}\text { Akaslan } \\
\& \text { Effie } \\
(2011)\end{array}$ \\
\hline 1. & Psychological & $\sqrt{ }$ & $\sqrt{ }$ & $\sqrt{ }$ & $\sqrt{ }$ & - & - & $\sqrt{ }$ & - \\
\hline 2. & Sociological & $\sqrt{ }$ & $\sqrt{ }$ & $\sqrt{ }$ & - & - & - & - & - \\
\hline 3. & Environmental & $\sqrt{ }$ & $\sqrt{ }$ & - & - & - & - & - & - \\
\hline
\end{tabular}




\begin{tabular}{|c|c|c|c|c|c|c|c|c|c|}
\hline 4. & $\begin{array}{l}\text { Human } \\
\text { Resource }\end{array}$ & $\sqrt{ }$ & $\sqrt{ }$ & $\sqrt{ }$ & $\sqrt{ }$ & $\sqrt{ }$ & $\sqrt{ }$ & $\sqrt{ }$ & $\sqrt{ }$ \\
\hline 5. & Financial & $\sqrt{ }$ & $\sqrt{ }$ & - & - & $\sqrt{ }$ & - & - & - \\
\hline 6. & $\begin{array}{l}\text { Knowledge } \\
\text { \&Skill }\end{array}$ & $\sqrt{ }$ & $\sqrt{ }$ & $\sqrt{ }$ & $\sqrt{ }$ & $\sqrt{ }$ & $\sqrt{ }$ & $\sqrt{ }$ & - \\
\hline 7. & $\begin{array}{l}\text { ICT } \\
\text { Infrastructure }\end{array}$ & $\sqrt{ }$ & $\sqrt{ }$ & - & $\sqrt{ }$ & $\sqrt{ }$ & $\sqrt{ }$ & $\sqrt{ }$ & $\sqrt{ }$ \\
\hline 8. & Content & $\sqrt{ }$ & - & - & - & - & $\sqrt{ }$ & $\sqrt{ }$ & $\sqrt{ }$ \\
\hline 9. & Management & - & - & - & - & $\sqrt{ }$ & $\sqrt{ }$ & - & $\sqrt{ }$ \\
\hline 10. & Leadership & - & - & - & - & $\sqrt{ }$ & $\sqrt{ }$ & - & - \\
\hline 11. & Culture & - & - & - & $\sqrt{ }$ & - & - & - & - \\
\hline 12. & Policy & - & - & - & - & $\sqrt{ }$ & - & - & - \\
\hline 13. & $\begin{array}{l}\text { Teacher } \\
\text { Experience }\end{array}$ & - & $\sqrt{ }$ & $\sqrt{ }$ & $\sqrt{ }$ & - & - & - & - \\
\hline 14. & Training & - & $\sqrt{ }$ & $\sqrt{ }$ & $\sqrt{ }$ & - & - & - & - \\
\hline 15. & $\begin{array}{l}\text { Organization } \\
\text { Structure }\end{array}$ & - & $\sqrt{ }$ & - & - & - & - & - & - \\
\hline 16. & $\begin{array}{l}\text { Technical } \\
\text { Support }\end{array}$ & - & - & $\sqrt{ }$ & $\sqrt{ }$ & - & - & - & - \\
\hline 17. & $\begin{array}{ll}\text { Laws } & \& \\
\text { Regulation } & \\
\end{array}$ & - & - & - & - & - & $\sqrt{ }$ & - & - \\
\hline
\end{tabular}

Table 2. Readiness Factors Based on Frequency.

\begin{tabular}{llc}
\hline No & \multicolumn{1}{c}{ ELR Factors } & Frequency \\
\hline 1. & Human Resource & 8 \\
\hline 2. & ICT Infrastructure & 7 \\
\hline 3. & Knowledge \& Skill & 7 \\
\hline 4. & Psychological & 5 \\
\hline 5. & Content & 4 \\
\hline 6. & Management & 3 \\
\hline 7. & Sociological & 3 \\
\hline 8. & Financial & 3 \\
\hline 9. & Training & 3 \\
\hline 10. & Teacher Experience & 3 \\
\hline 11. & Leadership & 2 \\
\hline 12. & Technical Support & 2 \\
\hline 13. & Environmental & 2 \\
\hline 14. & Organization Structure & 1 \\
\hline 15. & Culture & 1 \\
\hline 16. & Laws \& Regulation & 1 \\
\hline 17. & Policy & 1 \\
\hline
\end{tabular}

Table 3. Mapping of ELR Factors towards the McKensey 7S Framework

\begin{tabular}{ccc}
\hline No & McKensey 7S Dimension & ELR Factors \\
\hline 1. & Strategy & Policy; Financial; Laws \& Regulation \\
\hline 2. & Structure & Organization Structure \\
\hline 3. & Systems & ICT Infrastructure; Technical Support; Content \\
\hline 4. & Style/Culture & Culture; Leadership; Management \\
\hline 5. & Staff & Human Resource; Training \\
\hline 6. & Skills & Knowledge \& Skill; Teacher Experience \\
\hline 7. & Shared Values & Psychological; Sociological; Environment \\
\hline
\end{tabular}


Based on Table 3 above it can be seen that the overall factor of readiness of e-learning can be mapped into the McKensey 7S framework consisting of: Strategy related to Actions of a company plans in response to changes in its external environment; Structure related Bases of specialization and co-ordination influenced primarily by strategy, size, and diversity of organization; Systems related to formal and informal procedures that support the strategy and structure; Style/Culture consisting of two components as below: Organizational culture: the dominant values, beliefs, and norms which develops over time and relative features of organizational life. Management style: more a matter of what managers do than what they say; how do company managers spend their time; what are they focusing on; Staff is the people / human resource management-processes used to develop managers, socialization processes, and ways of introducing the young recruits to the company; Skills related to the distinctive competences- what the organization does best; and Shared values related to Guiding concepts, fundamental ideas around which a business is built- must be simple, have great meaning inside the organization even though outsiders may not see or understand them (Alshaher. A A., 2013).

\section{Conclusion}

ELR model is useful not only to measure the level of readiness of the organization in implementing e-learning, but also to know the factors of readiness of what have been strong and still weak so that require corrective action or improvement. ELR model is not only used once but continuously to maintain sustainability of e-learning system. This research has succeeded to formulate ELR model which contains various factors related to readiness of elearning implementation. These factors have been mapped into several dimensions based on the McKensey 7S model to obtain 7 (seven) dimensions: strategy, structure, systems, style/culture, staff, skills and shared values.

\section{Acknowledgments}

We would like to thank the research institution that has supported the research activities was being carried out properly.

\section{Reference}

[1] Achieng, H. (2013) 'ELR Assessment Model in Kenya's Higher Education Institutions: A Case Study Of University Of Nairobi.'

[2] Akaslah, D., Effie, L. (2011) 'Measuring teacher's readiness for e-learning in higher education institutions associated with the subject electricity in turkey Global engineering education conference - Learning environments and ecosystems in engineering education, IEEE.'

[3] Alshaher. A A. (2013) 'The McKinsey 7S Model Framework for E-learning System Readiness Assessment.', International Journal of advance in Engineering \& Technology (IJAET), 6(5), pp. 1948-1966.

[4] Aydin C H., Tasci, D. (2005) 'Measuring Readiness for eLearning: Reflections from an Emerging Country Educational Technology \& Society’, 8(4), pp. 244-257.

[5] Borotis, S., Poulymenakou, A. (2004) 'E-Learning Readiness Components: Key Issues to Consider before adopting e-Learning Interventions'. Available at: http://www.eltrun.gr/papers/eLReadiness_ELEARN2004.pdf . 
[6] Chapnick, S. (2000) 'E-learning Readiness TM Assessment by Samanta Chapnick (2001) Are You Ready for E-Learning?'

[7] Darab, B., Montazer, G. A. (2011) An Electric Model for Assessing E-learning Readiness in the Iranian universities. Computers and Education.

[8] Kaur, K., Abas, Z. (2004) 'An Assessment of E-Learning Readiness at the Open University Malaysia.', in International Conference on Computer in Education. Melbourne. Melbourne.

[9] Landipayana, H. N. (2013) 'Evaluasi E-learning Menggunakan Value Model (Studi Kasus E-learning Jurusan Sistem Informasi Institut Teknologi SepuluhNopember).'

[10] Prayudi, Y. (2009) 'Awal: E-Learning Readiness Index (ELRI) Sebagai Model Bagi Evaluasi E-Learning Pada Sebuah Institusi.', in Seminar Nasional Aplikasi Teknologi Informasi 2009 Universitas Islam Indonesia. YOGYAKARTA.

[11] Priyanto (2008) 'Model E-learning Readiness Sebagai Strategi Pengembangan Elearning. University.', in International Seminar Proceedings, Information Communication Technology (ICT) In Education. The Graduate School. Yogyakarta State University.

[12] Rachman T., Napitupulu D. (2017) 'Rasch Model for Validation a User Acceptance Instrument for Evaluating E-Learning System.', CommIT (Communication \& Information Technology) Journal, 11(1), pp. 9-16.

[13] Ralmugiz, U. (2015) 'Aplikasi Model McKinsey 7S Untuk Evaluasi Penerapan Elearning di Sekolah Menengah Atas Bopkri Yogyakarta.', in Skripsi Fakultas Matematika dan Ilmu Pengetahuan Alam. Universitas Negeri Yogyakarta.

[14] Rohmah, L. (2016) 'Konsep E-Learning dan Aplikasinya pada Lembaga Pendidikan Islam. An-Nur', 3

[15] Rosenberg, M.J. (2006) 'What Lies Beyond E-Learning?'

[16] Saekow, A., Samson, D. (2011) 'E-learning Readiness of Thailand's Universities Comparing to the USA's Cases.', International Journal of E-Education, E-Business, E-Management, and E-Learning, 1(2).

[17] Sensuse, D I., Napitupulu, D. (2017) 'The Study of User Acceptance Toward ELearning System in Higher Education.', nternational Journal of Electrical Engineering and Computer Science, 7 (2), pp. 466-473.

[18] Sun, P.C., et all (2008) 'What drives a successful eLearning?An empirical investigation of the critical factors influencing learner satisfaction Computer \& Education', pp. 1183-1202.

[19] Swatman, T., So, T. (2005) 'E-Learning Readiness in The Classroom: A Study of Hongkong Primary and Secondary Teachers Fifth IEEE.', in International Conferene on Advanced Learning Technologies.

[20] Waryanto, N. . (2014) 'Tingkat Kesiapan (Readiness) Implementasi E-Learning di Sekolah Menengah Atas Kota Yogyakarta.'

[21] Wattakiecharoen, J., Nilsook, P. (2013) 'E - Learning Readiness of PhD Students.', in International Conference on Excellent Innovation for Educational Research and IT Learning in the 21st Century. Nakhon Pathom. 